\title{
Spatial variability of snow chemistry in western Dronning Maud Land, Antarctica
}

\author{
Malin Stenberg, ${ }^{1}$ Elisabeth Isaksson, ${ }^{2}$ Margareta Hansson, ${ }^{3}$ Wibjörn Karlén, ${ }^{1}$ \\ Paul A. Mayewski, ${ }^{4}$ Mark S. Twigkler, ${ }^{4}$ Sallie I. Whitlow, ${ }^{4}$ Niels Gundestrup ${ }^{5}$ \\ ${ }^{1}$ Department of Physical Geography, Stockholm University, S-106 91 Stockholm, Sweden \\ ${ }^{2}$ Norwegian Polar Institute, Middlethuns gt. 29, Box 5072-Majorstua, N-0301 Oslo, Norway \\ ${ }^{3}$ Department of Meteorology, Stockholm University, S-106 91 Stockholm, Sweden \\ ${ }^{4}$ Glacier Research Group, Institute for the Study of Earth, Oceans and Space, University of New Hampshire, Durham, NH 03824, U.S.A. \\ ${ }^{5}$ The Niels Bohr Institute, Department of Geophysics, University of Copenhagen, Juliane Maries Vej 30, DK-2100 Copenhagen 0 , Denmark
}

\begin{abstract}
During the austral summer of 1993-94 a number of 1-2 $\mathrm{m}$ deep snow pits were sampled in connection with firn-coring in western Dronning Maud Land, Antarctica. The traverse went from 800 to about $3000 \mathrm{~m}$ a.s.l. upon the high-altitude plateau. Profiles of cations $\left(\mathrm{Na}^{+}, \mathrm{K}^{+}, \mathrm{Mg}^{2+}, \mathrm{Ca}^{2+}\right)$, anions $\left(\mathrm{Cl}^{-}, \mathrm{NO}^{3-}, \mathrm{SO}_{4}{ }^{2-}, \mathrm{CH}_{3} \mathrm{SO}_{3}^{-}\right)$and stable oxygen isotopes $\left(\delta^{18} \mathrm{O}\right)$ from 11 snow pits are presented here. Close to the coast $2 \mathrm{~m}$ of snow accumulates in about 2-3 years, whilst at sites on the high-altitude plateau $2 \mathrm{~m}$ of snow accumulates in 10-14 years. The spatial variation in ion concentrations shows that the ions can be divided into two groups, one with sea-salt elements and methane sulfonate and the other with nitrate and sulfate. For the sea-salt elements and methane sulfonate the concentrations decrease with increasing altitude and increasing distance from the coast, as well as with decreasing temperature and decreasing accumulation rate. For nitrate and sulfate the concentrations are constant or increase with respect to these parameters. This pattern suggests that the sources for sea-salt elements and methane sulfonate are local, whereas the sources for nitrate and sulfate are a mixture of local and long-range transport.
\end{abstract}

\section{INTRODUCTION}

An understanding of the spatial variability and of the factors controlling the distribution of ions is essential for the interpretation of ion chemistry records from deep ice cores drilled at a single site. Snow-pit studies are a useful tool for the study of the spatial variability since we can directly compare variations in the snow chemistry with meteorological measurements and thus interpret variations in sources, transport and deposition processes. A number of different traverses and studies have been conducted to map the trends in chemistry over the Antarctic continent. Mulvaney and Wolff (1994) compiled the spatial variability of concentrations of major anions $\left(\mathrm{Cl}^{-}, \mathrm{NO}^{3-}, \mathrm{SO}_{4}{ }^{2-}\right)$ in Antarctic snow and firn. This study shows that there are still large areas of the continent where data are lacking.

In order to improve the coverage of data, a Swedish expedition visited the coastal area and the polar plateau in western Dronning Maud Land (DML) during the austral summer of 1993-94 (Fig. 1). This area of DML is of particular interest because it has been selected as a potential deepdrilling site by the European Project for Ice Coring in Antarctica. The traverse was performed as a part of the International Trans-Antarctic Scientific Expedition. The major objectives of the program include study of the spatial variability of ions, stable oxygen isotopes and snow accumulation and also the climate variability during the last 100 200 years using shallow firn cores. Both firn cores and snow samples from pits were collected during the expedition, and

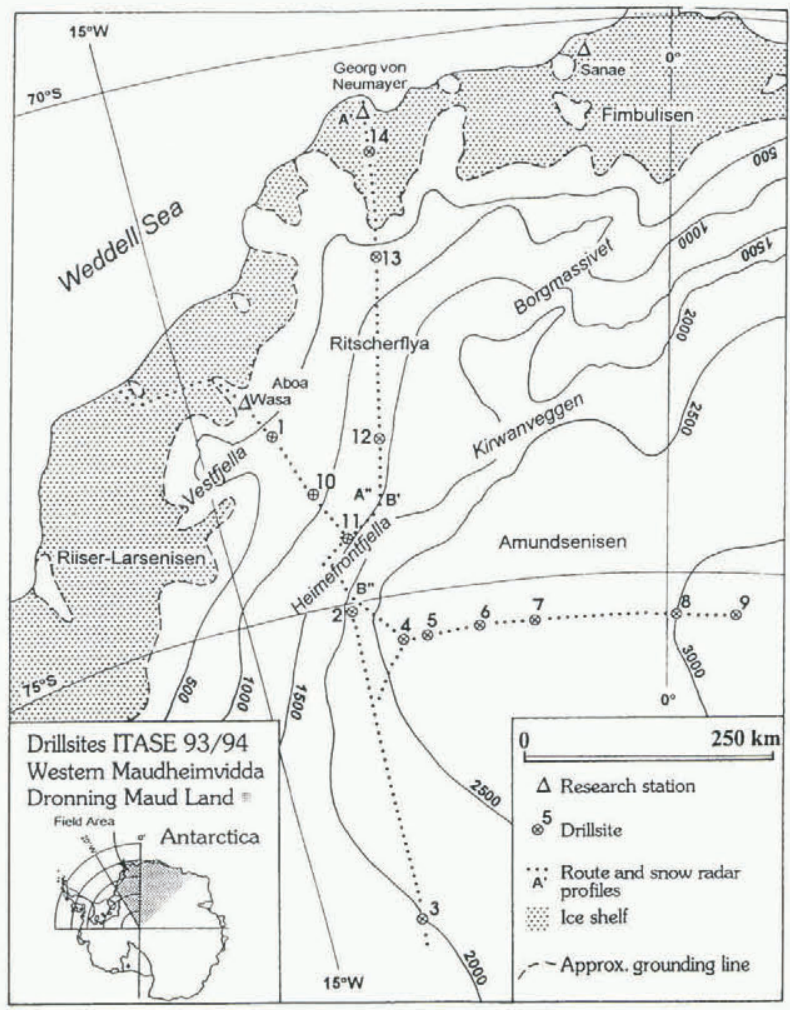

Fig. 1. Map showing locations of the snow pits in western Dronning Maud Land, Antarctica. 
in this paper we report the results from the snow pits. The aims of the snow-pit study were to investigate the spatial variability of ions $\left(\mathrm{Na}^{+}, \mathrm{K}^{+}, \mathrm{Mg}^{2+}, \mathrm{Ca}^{2+}, \mathrm{Cl}^{-}, \mathrm{NO}^{3-}\right.$, $\mathrm{SO}_{4}{ }^{2-}, \mathrm{CH}_{3} \mathrm{SO}_{3}{ }^{-}$) and oxygen isotopes and to study the influence of different parameters such as altitude, distance from sources, temperature, snow-accumulation rate and aerosol properties on the spatial variability of the different ions. The spatial variability is particularly important when looking at different ratios such as the ratio between $\mathrm{CH}_{3} \mathrm{SO}_{3}{ }^{-}$and $\mathrm{SO}_{4}{ }^{2-}$.

Only a few studies of snow chemistry have been conducted in western DML. Major ions were measured from the coast to $120 \mathrm{~km}$ inland on the Riiser-Larsenisen ice shelf (Gjessing, 1984). One $20 \mathrm{~m}$ long firn core from the high-altitude plateau $\left(75^{\circ} \mathrm{S}, 2^{\circ} \mathrm{E}\right)$ has been analyzed for major anions and cations (Isaksson, 1994). At a few stations along the coast of Antarctica, air samples of major chemical components have been measured in order to study seasonal cycles. At the German coastal station Georg von Neumayer in DML (Fig. 1) year-round measurements have been conducted since 1983 (Wagenbach and others, 1988).

\section{SITE DESCRIPTION}

The traverse started in the coastal area on the flat RiiserLarsenisen ice shelf (Fig. 1) and continued over the undulating ice surface northwest of the mountain range Heimefrontfjella. There is an increase in altitude at Heimefrontfjella of about $1000 \mathrm{~m}$ up to the high-altitude plateau, Amundsenisen. At Amundsenisen the surface topography is relatively flat, and in part of this area sastrugi, typically a few meters long and $10-50 \mathrm{~cm}$ high, are frequent.

\section{Table 1. Site locations and general field data}

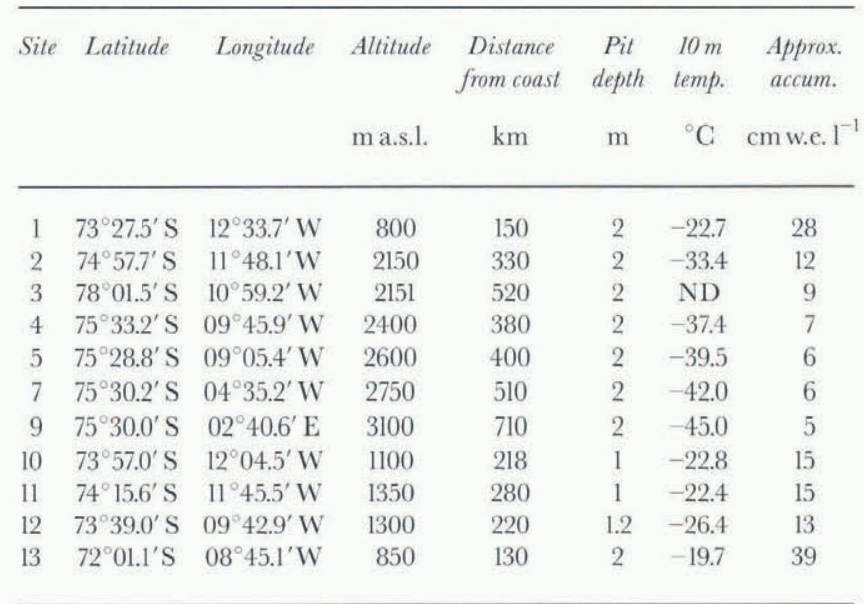

The coring sites were chosen to cover as much distance as possible between the coast and the polar plateau in order to determine the spatial variability of ions and oxygen isotopes. Altogether, 14 cores were drilled to a depth of $10-$ $30 \mathrm{~m}$, and $1-2 \mathrm{~m}$ deep snow pits were dug at each drilling site. In this paper we present data from the 11 snow pits that have been analyzed so far, from 800 up to $3000 \mathrm{~m}$ a.s.l. distributed over a distance of about $700 \mathrm{~km}$ (Fig. 1; Table 1). Site altitudes vs distance from the coast are shown in Figure 2.

Previous glaciological studies in this coastal area have shown that the snow-accumulation rate decreases rapidly with increasing distance from the sea, from about $40 \mathrm{~cm}$ w.e. $\mathrm{a}^{-1}$ on the Riiser-Larsenisen ice shelf to $<8 \mathrm{~cm}$ w.e. $\mathrm{a}^{-1}$ at $3000 \mathrm{~m}$ a.s.l. (Isaksson and Karlén, 1994a, b; Isaksson and others, 1996). Continuous snow radar measurements made along the same traverse route have revealed a large spatial variability in snow accumulation rate (Richardson and others, 1997). The radar surveys showed that the accumulation rate varies considerably in the coastal region, which has an undulating topography. Even larger variations can be found in areas with a large altitudinal gradient, such as the grounding line and around Heimefrontfjella. On the flat, high-altitude plateau the variations in accumulation are less pronounced (Richardson and others, 1997). The seasonal variation and frequency of precipitation is of importance for the snow record of wet scavenged atmospheric components. Accumulation rates from stake measurements in this area have indicated that only $3-23 \%$ of the total accumulation can be attributed to the summer season from December to February (Näslund and others, 1991).

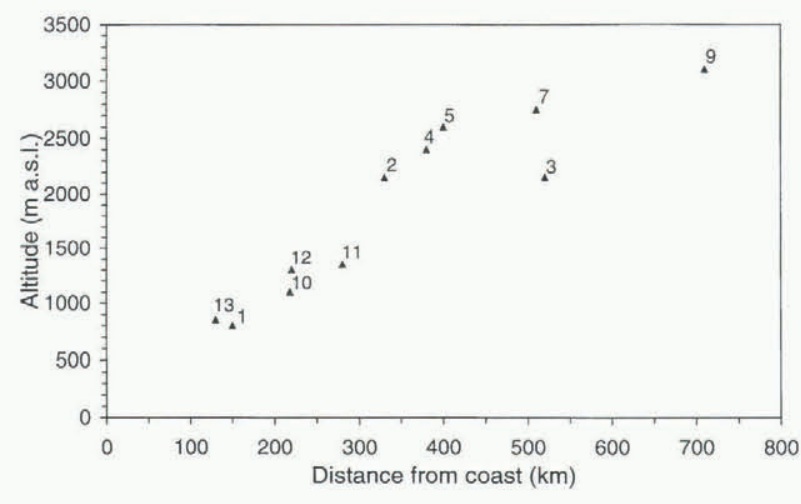

Fig. 2. Site altitudes ( $m$ a.s.l.) vs distance from coast $(\mathrm{km})$. Locations of sites are given in Figure 1 .

\section{SAMPLING}

At each coring site a shallow (1-2 m) snow pit was dug $100 \mathrm{~m}$ upwind from local contamination sources. The spoils were dumped in the downwind direction in order to avoid direct contamination. The sampling wall, at the upwind side of the pit, was cleaned by removing $15-20 \mathrm{~cm}$ with a shovel and an additional $4-5 \mathrm{~cm}$ with a scraper. The sampling was performed by personnel wearing clean suits, polyethylene gloves and face masks. All tools used for digging and sampling were made of Plexiglas or polyethylene, and were thoroughly washed with double-deionized water (resistivity $>18 \mathrm{M} \Omega$ ) from a Milli-Q system. Samples for ion analysis and stable oxygen isotope analysis were taken at $2 \mathrm{~cm}$ intervals, and for density measurements at $3 \mathrm{~cm}$ intervals. Samples for chemical analyses were collected in precleaned (double-deionized water) $60 \mathrm{ml}$ polypropylene bottles (Nalgene). The bottles were stored in a freezer $\left(-15^{\circ} \mathrm{C}\right)$ during subsequent transport by ship to the freeze room $\left(-25^{\circ} \mathrm{C}\right)$ at the Department of Meteorology, Stockholm University. Some of the samples for ion analysis were flown directly from Cape Town to the University of New Hampshire. All samples were kept frozen during transport and were melted just prior to analysis.

\section{ANALYTICAL METHODS}

Ion concentrations were measured by ion chromatography 
(Dionex). Samples from snow pits 1-4 were analyzed at the University of New Hampshire, and samples from snow pits 5-13 were analyzed at the Department of Meteorology, Stockholm University. Comparisons were made between the two laboratories, and the results showed good agreement. Separator columns (AS4A), eluent $1.8 \mathrm{mM} \mathrm{Na}_{2} \mathrm{CO}_{3}$ and $1.7 \mathrm{mM} \mathrm{NaHCO}$, were used for analyses of anions $\left(\mathrm{Cl}^{-}, \mathrm{NO}^{3-}, \mathrm{SO}_{4}{ }^{2-}\right)$, and $\mathrm{CS} 12$ columns with eluent $20 \mathrm{mM}$ methane sulfonic acid were used for analyses of cations $\left(\mathrm{Na}^{+}\right.$, $\left.\mathrm{K}^{+}, \mathrm{Mg}^{2+}, \mathrm{Ca}^{2+}\right)$. Methane sulfonate $\left(\mathrm{CH}_{3} \mathrm{SO}_{3}{ }^{-}\right.$, also commonly abbreviated $\mathrm{MSA}^{-}$) was analyzed separately on AS4 columns with eluent $7 \mathrm{mM} \mathrm{NaOH}$ and $100 \mathrm{mM} \mathrm{NaOH}$ or $0.5 \mathrm{mM} \mathrm{NaHCO}$. The average analytical error was estimated to be less than $+10 \%$ for all ions reported.

Potassium concentrations are not reported for snow pits 5-13 due to insufficient separation from an unknown peak in the chromatogram. Neither are $\mathrm{Ca}^{2+}$ values reported for those pits, due to too high background concentrations.

The stable oxygen isotope analysis was performed by mass spectroscopy at the Department of Geophysics, University of Copenhagen. The $\delta^{18} \mathrm{O}$ value, expressed in \%, describes the relative deviation of ${ }^{18} \mathrm{O}$ in the precipitation compared to Standard Mean Ocean Water (Dansgaard, 1964). The measuring accuracy is better than $0.1 \%$.

\section{RESULTS AND DISCUSSION}

General information for each snow pit is presented in Table 1 , and chemical data for eight ions and $\delta^{18} \mathrm{O}$ are given in Table 2. Dating of the snow stratigraphy was performed using all available data on seasonal chemical variations. The depth of the snow pits varied between 1 and $2 \mathrm{~m}$. At the coast $2 \mathrm{~m}$ of snow accumulate in about $2-3$ years, while at high-altitude sites $2 \mathrm{~m}$ of snow accumulate in about 1014 years. Thus, the mean concentrations represent snow accumulated over 2-14 years. In order to compare data from the same time period, a mean value for the two most recent years was calculated for each snow pit (in parentheses in Table 2). This 2 year mean value was found not to deviate more than $30 \%$ from the overall mean value, except for elevated mean values for $\mathrm{NO}_{3}{ }^{-}, \mathrm{SO}_{4}{ }^{2-}$ and $\mathrm{CH}_{3} \mathrm{SO}_{3}{ }^{-}$in the snow pits from the high-altitude plateau (pits 2-5,7 and 9). For $\mathrm{NO}_{3}{ }^{-}$this is in accordance with suggested post-depositional losses of $\mathrm{HNO}_{3}$ (Neubauer and Heumann, 1988) which lead to an increase of the $\mathrm{NO}_{3}{ }^{-}$concentration toward the surface. The elevated concentrations of $\mathrm{SO}_{4}{ }^{2-}$ in the upper snow layers can be attributed to the eruption of Mount Pinatubo in 1991, which greatly increased the stratospheric loading of $\mathrm{SO}_{4}{ }^{2-}$ aerosols over Antarctica during 1991-93 (e.g. Caccianni and others, 1993; Hoffmann and others, 1994; Saxena and others, 1995), or to the change in circulation pattern during the 1991-93 El Niño event. The elevated concentrations of $\mathrm{CH}_{3} \mathrm{SO}_{3}{ }^{-}$can be attributed to the El Niño event. This connection between elevated $\mathrm{CH}_{3} \mathrm{SO}_{3}{ }^{-}$concentrations in Antarctic snow and El Niño circulation pattern was first suggested by Legrand and Feniet-Saigne (1991) based on a record from the South Pole. Both the volcanic signal and the signal attributed to the 1991-93 El Niño event have been observed in snow pits at the South Pole (Dibb and Whitlow, 1996).

The ratio between $\mathrm{Cl}^{-}$and $\mathrm{Na}^{+}$(Fig. 3) varies from a minimum of 1.16, close to the sea-water molar ratio, up to single maximum values of 14 at some sites. No surplus of $\mathrm{Na}^{+}$compared to $\mathrm{Cl}^{-}$is noted in any sample. We chose to use $\mathrm{Na}^{+}$, in accordance with most other investigators of Antarctic snow and ice chemistry, as the sea-salt indicator for calculation of the non-sea-salt (nss) fraction of the total con-

Table 2. Chemical data with mean ion concentrations (in $\mu$ eq $\Gamma^{I}$ ) and $\delta^{18} \mathrm{O}$ (in $\%$ ). $\mathrm{R}$ is the molar ratio of $\left(\mathrm{CH}_{3} \mathrm{SO}_{3}{ }^{-}\right.$) $\mathrm{CH}_{3} \mathrm{SO}_{3}{ }^{-}+n s s \mathrm{SO}_{4}{ }^{2-}$ ). This ratio and the $\mathrm{CI} / \mathrm{Na}^{+}$molar ratio are given as mean values of individual ratios. In parentheses are the mean values for the years 1992 and 1993

\begin{tabular}{|c|c|c|c|c|c|c|c|c|c|c|c|c|c|c|c|c|}
\hline Site & $\mathrm{Na}^{+}$ & $\kappa^{+}$ & $n s s K^{+}$ & $\mathrm{Mg}^{2+}$ & $n s s \mathrm{Mg}^{2+}$ & $\mathrm{Ca}^{2+}$ & $n s s \mathrm{Ca}^{2+}$ & $\mathrm{Cl}$ & $n s s \mathrm{Cl}$ & $\mathrm{NO}_{3}$ & $\mathrm{SO}_{1}{ }^{2}$ & $n s s \mathrm{SO}_{4}{ }^{2}$ & $\mathrm{CH}_{3} \mathrm{SO}_{3}$ & $R I^{-}$ & $\mathrm{Cl} / \mathrm{Na}^{+}$ & $\delta^{18} O$ \\
\hline 1 & $\begin{array}{r}2.28 \\
(1.67)\end{array}$ & $\begin{array}{c}0.06 \\
(0.05)\end{array}$ & 0.01 & $\begin{array}{c}0.58 \\
(0.42)\end{array}$ & 0.06 & $\begin{array}{c}0.12 \\
(0.09)\end{array}$ & 0.02 & $\begin{array}{l}2.98 \\
(2.32)\end{array}$ & 0.33 & $\begin{array}{c}0.73 \\
(0.81)\end{array}$ & $\begin{array}{r}1.45 \\
(1.45)\end{array}$ & 1.17 & $\begin{array}{c}0.18 \\
(0.20)\end{array}$ & 0.27 & 1.5 & $\begin{array}{l}-26.0 \\
(-26.0)\end{array}$ \\
\hline 2 & $\begin{array}{l}0.80 \\
(0.81)\end{array}$ & $\begin{array}{c}0.04 \\
(0.04)\end{array}$ & 0.02 & $\begin{array}{c}0.20 \\
(0.20)\end{array}$ & 0.04 & $\begin{array}{l}0.06 \\
(0.06)\end{array}$ & 0.03 & $\begin{array}{c}1.14 \\
(1.08)\end{array}$ & 0.22 & $\begin{array}{c}0.83 \\
(0.79)\end{array}$ & $\begin{array}{l}1.48 \\
(1.90)\end{array}$ & 1.38 & $\begin{array}{c}0.11 \\
(0.15)\end{array}$ & 0.17 & 1.9 & $\begin{array}{l}-37.7 \\
(-37.9)\end{array}$ \\
\hline 3 & $\begin{array}{c}0.47 \\
(0.54)\end{array}$ & $\begin{array}{c}0.02 \\
(0.03)\end{array}$ & 0.01 & $\begin{array}{l}0.12 \\
(0.15)\end{array}$ & 0.02 & $\begin{array}{l}0.06 \\
(0.05)\end{array}$ & 0.04 & $\begin{array}{c}0.78 \\
(0.86)\end{array}$ & 0.22 & $\begin{array}{c}0.79 \\
(0.95)\end{array}$ & $\begin{array}{l}1.28 \\
(1.93)\end{array}$ & 1.22 & $\begin{array}{l}0.09 \\
(0.16)\end{array}$ & 0.14 & 1.9 & ND \\
\hline 4 & $\begin{array}{c}0.92 \\
(0.67)\end{array}$ & $\begin{array}{c}0.03 \\
(0.03)\end{array}$ & 0.01 & $\begin{array}{l}0.25 \\
(0.18)\end{array}$ & 0.04 & $\begin{array}{l}0.06 \\
(0.06)\end{array}$ & 0.02 & $\begin{array}{c}1.33 \\
(1.09)\end{array}$ & 0.27 & $\begin{array}{l}0.89 \\
(1.67)\end{array}$ & $\begin{array}{c}1.50 \\
(2.08)\end{array}$ & 1.39 & $\begin{array}{c}0.09 \\
(0.09)\end{array}$ & 0.11 & 2.0 & $\begin{array}{c}-40.2 \\
(-38.7)\end{array}$ \\
\hline 5 & ND & ND & ND & ND & ND & ND & ND & $\begin{array}{c}1.49 \\
(1.22)\end{array}$ & ND & $\begin{array}{c}1.0 \\
(1.36)\end{array}$ & $\begin{array}{c}1.66 \\
(2.01)\end{array}$ & ND & $\begin{array}{l}0.07 \\
(0.13)\end{array}$ & ND & ND & $\begin{array}{l}-41.1 \\
(-41.2)\end{array}$ \\
\hline 7 & $\begin{array}{c}0.64 \\
(0.46)\end{array}$ & ND & ND & $\begin{array}{c}0.22 \\
(0.17)\end{array}$ & 0.07 & ND & ND & $\begin{array}{c}1.17 \\
(1.31)\end{array}$ & 0.78 & $\begin{array}{c}1.10 \\
(2.67)\end{array}$ & $\begin{array}{c}2.08 \\
(2.76)\end{array}$ & 2.0 & $\begin{array}{c}0.06 \\
(0.07)\end{array}$ & 0.03 & 2.5 & $\begin{array}{c}-43.9 \\
(-44.7)\end{array}$ \\
\hline 9 & $\begin{array}{c}0.60 \\
(0.65)\end{array}$ & ND & ND & $\begin{array}{c}0.21 \\
(0.25)\end{array}$ & 0.07 & ND & ND & $\begin{array}{c}0.98 \\
(1.07)\end{array}$ & 0.33 & $\begin{array}{c}0.93 \\
(1.47)\end{array}$ & $\begin{array}{c}2.05 \\
(2.49)\end{array}$ & 1.98 & $\begin{array}{l}0.08 \\
(0.11)\end{array}$ & 0.07 & 2.1 & $\begin{array}{l}-46.1 \\
(-44.7)\end{array}$ \\
\hline 10 & $\begin{array}{c}2.4 \\
(1.78)\end{array}$ & ND & ND & $\begin{array}{c}0.70 \\
(0.53)\end{array}$ & 0.15 & ND & ND & $\begin{array}{c}3.52 \\
(2.44)\end{array}$ & 0.78 & $\begin{array}{c}0.88 \\
(0.93)\end{array}$ & $\begin{array}{c}2.51 \\
(2.85)\end{array}$ & 2.23 & $\begin{array}{c}0.12 \\
(0.18)\end{array}$ & 0.12 & 1.5 & $\begin{array}{l}-28.1 \\
(-27.1)\end{array}$ \\
\hline 11 & $\begin{array}{c}1.46 \\
(1.40)\end{array}$ & ND & ND & $\begin{array}{c}0.35 \\
(0.36)\end{array}$ & 0.21 & ND & ND & $\begin{array}{l}2.21 \\
(2.20)\end{array}$ & 0.43 & $\begin{array}{l}0.90 \\
(0.94)\end{array}$ & $\begin{array}{c}1.79 \\
(1.97)\end{array}$ & 1.52 & $\begin{array}{c}0.08 \\
(0.09)\end{array}$ & 0.09 & 2.0 & $\begin{array}{r}-31.5 \\
(-31.4)\end{array}$ \\
\hline 12 & $\begin{array}{c}1.15 \\
(1.14)\end{array}$ & ND & ND & $\begin{array}{c}0.36 \\
(0.31)\end{array}$ & 0.07 & ND & ND & $\begin{array}{c}1.67 \\
(1.45)\end{array}$ & 0.28 & $\begin{array}{c}1.13 \\
(1.13)\end{array}$ & $\begin{array}{c}2.10 \\
(2.16)\end{array}$ & 1.96 & $\begin{array}{c}0.12 \\
(0.15)\end{array}$ & 0.12 & 2.2 & $\begin{array}{l}-31.0 \\
(-27.1)\end{array}$ \\
\hline 13 & $\begin{array}{l}4.49 \\
(4.71)\end{array}$ & ND & ND & $\begin{array}{c}1.18 \\
(1.23)\end{array}$ & 0.14 & ND & ND & $\begin{array}{l}6.64 \\
(6.95)\end{array}$ & 1.40 & $\begin{array}{c}1.28 \\
(1.26)\end{array}$ & $\begin{array}{l}2.92 \\
(2.75)\end{array}$ & 2.38 & $\begin{array}{c}0.25 \\
(0.22)\end{array}$ & 0.23 & 2.0 & $\begin{array}{l}-22.7 \\
(-22.9)\end{array}$ \\
\hline
\end{tabular}


Snow pit 1

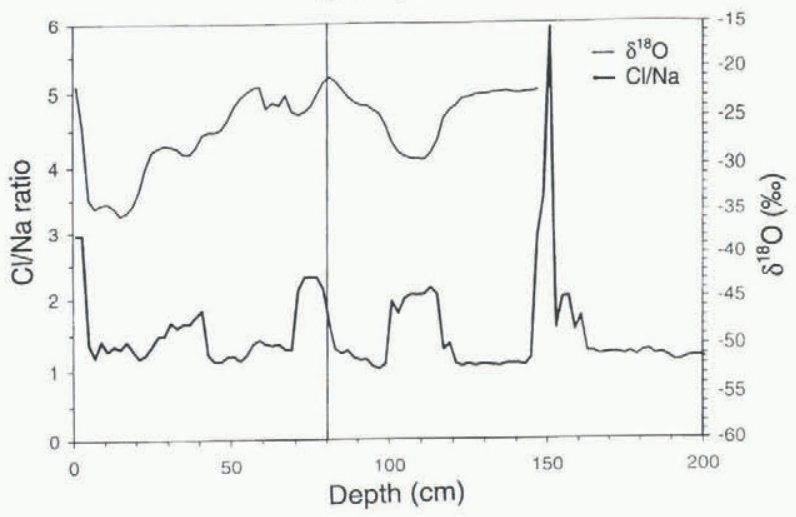

Snow pit 4

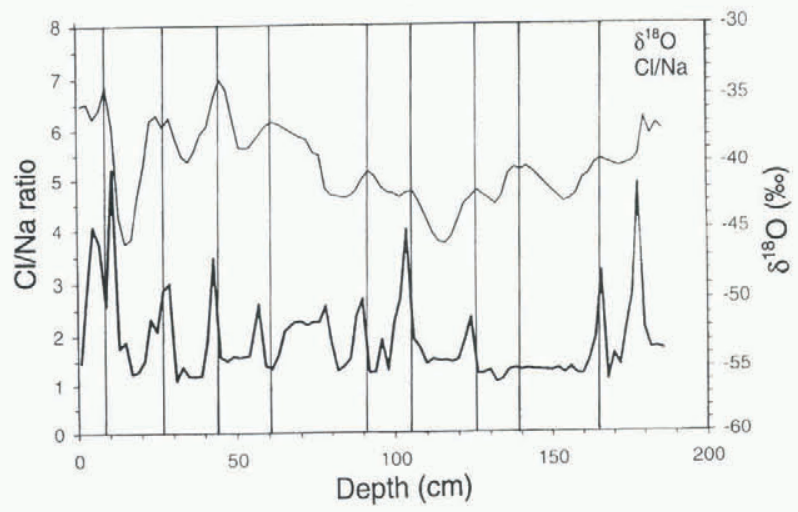

Fig. 3. $\mathrm{Cl} / \mathrm{Na}^{+}$molar ratio vs depth for a coastal site (1) and a high-altitude plateau site (4). The summer seasons in the oxygen isotope record are marked with vertical lines.

centrations of $\mathrm{K}^{+}, \mathrm{Mg}^{2+}, \mathrm{Ca}^{2+}, \mathrm{Cl}^{-}$and $\mathrm{SO}_{4}{ }^{2-}$. The nonsea-salt fraction for each ion is calculated by assuming a mean sea-water molar ratio of 0.022 for $\mathrm{K}^{+} / \mathrm{Na}^{+}, 0.23$ for $\mathrm{Mg}^{2+} / \mathrm{Na}^{+}, 0.044$ for $\mathrm{Ca}^{2+} / \mathrm{Na}^{+}, 1.16$ for $\mathrm{Cl} / \mathrm{Na}^{+}$and 0.12 for $\mathrm{SO}_{4}{ }^{2-} / \mathrm{Na}^{+}$. The ratio is multiplied by the actual $\mathrm{Na}^{+}$ concentration in each sample, and the product is then subtracted from the total concentration of the specific ion (with all concentrations expressed in $\mu$ eq $1^{-1}$ ), yielding the nss fraction of the specific ion. The calculated average sea-salt fraction at sites northeast of Heimefrontfjella is $80 \%$ for $\mathrm{K}^{+}$, $\mathrm{Mg}^{2+}, \mathrm{Ca}^{2+}$ and $\mathrm{Cl}^{-}$and $15 \%$ for $\mathrm{SO}_{4}{ }^{2}$. At sites on the polar plateau the calculated sea-salt fraction is less, on average $50 \%$ for $\mathrm{K}^{+}$and $\mathrm{Ca}^{2+}, 80 \%$ for $\mathrm{Mg}^{2+}, 70 \%$ for $\mathrm{Cl}^{-}$and $5 \%$ for $\mathrm{SO}_{4}{ }^{2-}$. This implies that other sources than sea spray may be important not only for $\mathrm{SO}_{4}{ }^{2-}$ but also for $\mathrm{K}^{+}, \mathrm{Mg}^{2+}$, $\mathrm{Ca}^{2+}$ and $\mathrm{Cl}^{-}$, or that fractionation of sea-salt aerosol occurs during transport inland (Mulvaney and others, 1993). A reaction between acid aerosols and sea salt producing gaseous $\mathrm{HCl}$, combined with more efficient transport and deposition of $\mathrm{HCl}$ gas to the snow, has been suggested as the major source of nss- $\mathrm{Cl}^{-}$in Antarctica (Legrand and Delmas, 1988).

\section{Oxygen isotopes and snow accumulation rates}

Annual dating of the snow stratigraphy with the help of the $\delta^{18} \mathrm{O}$ profiles was performed by counting the less negative $\delta^{18} \mathrm{O}$ summer peaks. The seasonal amplitude is typically 4$10 \%$, which is acceptable for dating in most cases. However, data from pits 2-9 show signs of diffusion due to the snow densification process which is typical for sites with low annual accumulation and large temperature differences between summer and winter (Johnsen, 1977). Since the rela- tive amounts of the different stable oxygen isotopes in the snow are to a large degree dependent on the temperature during formation of the precipitation (Dansgaard and others, 1973), the mean $\delta^{18} \mathrm{O}$ value for each pit is an indicator of the mean annual temperature at that site. The mean $\delta^{18} \mathrm{O}$ and the $10 \mathrm{~m}$ borehole temperature at each site are plotted vs altitude in Figure 4. The significant correlation $\left(r^{2}=0.98\right.$, $\sigma=9.22$ ) between the mean $\delta^{18} \mathrm{O}$ and the $10 \mathrm{~m}$ borehole temperature suggests that the $\delta^{18} \mathrm{O}$ mean values from this area are suitable as proxy-temperature indicators.

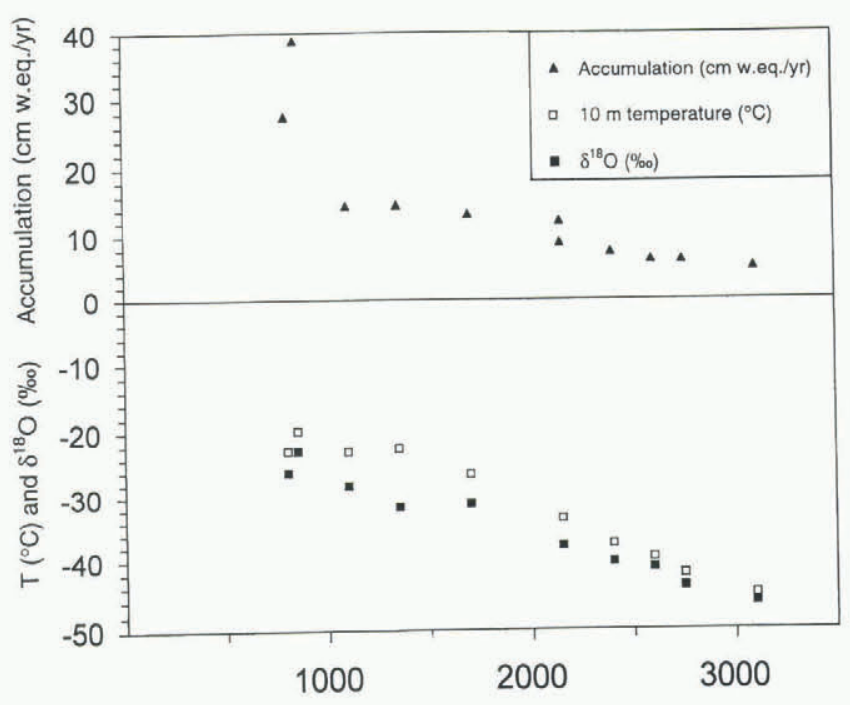

Fig. 4. The $10 \mathrm{~m}$ depth temperature $\left({ }^{\circ} \mathrm{C}\right.$ ), mean $\delta^{18} \mathrm{O}$ (\%o) and mean accumulation rate (cmw.e. $\left.a^{-I}\right)$ at each site vs altitude.

The mean $\delta^{18} \mathrm{O} / 10 \mathrm{~m}$ temperature gradient for this dataset is $0.91 \%{ }^{\circ} \mathrm{C}^{-1}$. In another dataset using $10 \mathrm{~m}$ firn cores from the Riiser-Larsenisen ice shelf and up to Amundsenisen, the gradient was $1.16 \%{ }^{\circ} \mathrm{C}^{-1}$ (Isaksson and Karlén, $1994 \mathrm{a}, \mathrm{b})$. This is higher than the $0.75 \%{ }^{\circ} \mathrm{C}^{-1}$ gradient that is generally used in East Antarctica (Lorius and Merlivat, 1977). If only the sites above $2000 \mathrm{~m}$ are used, the mean $\delta^{18} \mathrm{O} / 10 \mathrm{~m}$ temperature gradient becomes $0.74 \%{ }^{\circ} \mathrm{C}^{-1}$ $\left(r^{2}=0.98, \sigma=3.11\right)$. In agreement with our previous studies in the area, we find the better-defined $10 \mathrm{~m}$ temperature/mean $\delta^{18} \mathrm{O}$ relationship at high-altitude sites the result of a more stable (i.e. better-mixed) moisture source than at more coastal sites (Isaksson and Karlén, 1994a, b; Isaksson and others, 1996). In a study by Qin Dahe and others (1994) it was also observed that on the polar plateau the gradient of the mean $\delta^{18} \mathrm{O} / 10 \mathrm{~m}$ temperature regression line could shift. These studies show that it is important to be aware of the regional character of the mean $\delta^{18} \mathrm{O} / 10 \mathrm{~m}$ temperature gradient when using $\delta^{18} \mathrm{O}$ mean values as proxy-temperature indicators.

Calculation of the annual accumulation was done using the summer peaks in the $\delta^{18} \mathrm{O}$ record or, when this was indistinct, the seasonal variation in the ion records. There was a large variation $(60 \%)$ in accumulation between years. However, the mean accumulation for each pit (Table 1) was in agreement with previous accumulation measurements in the area (Isaksson and Karlén, 1994a, b; Isaksson and others, 1996). The spatial trend shows decreasing values with increasing altitude (Fig. 4). 


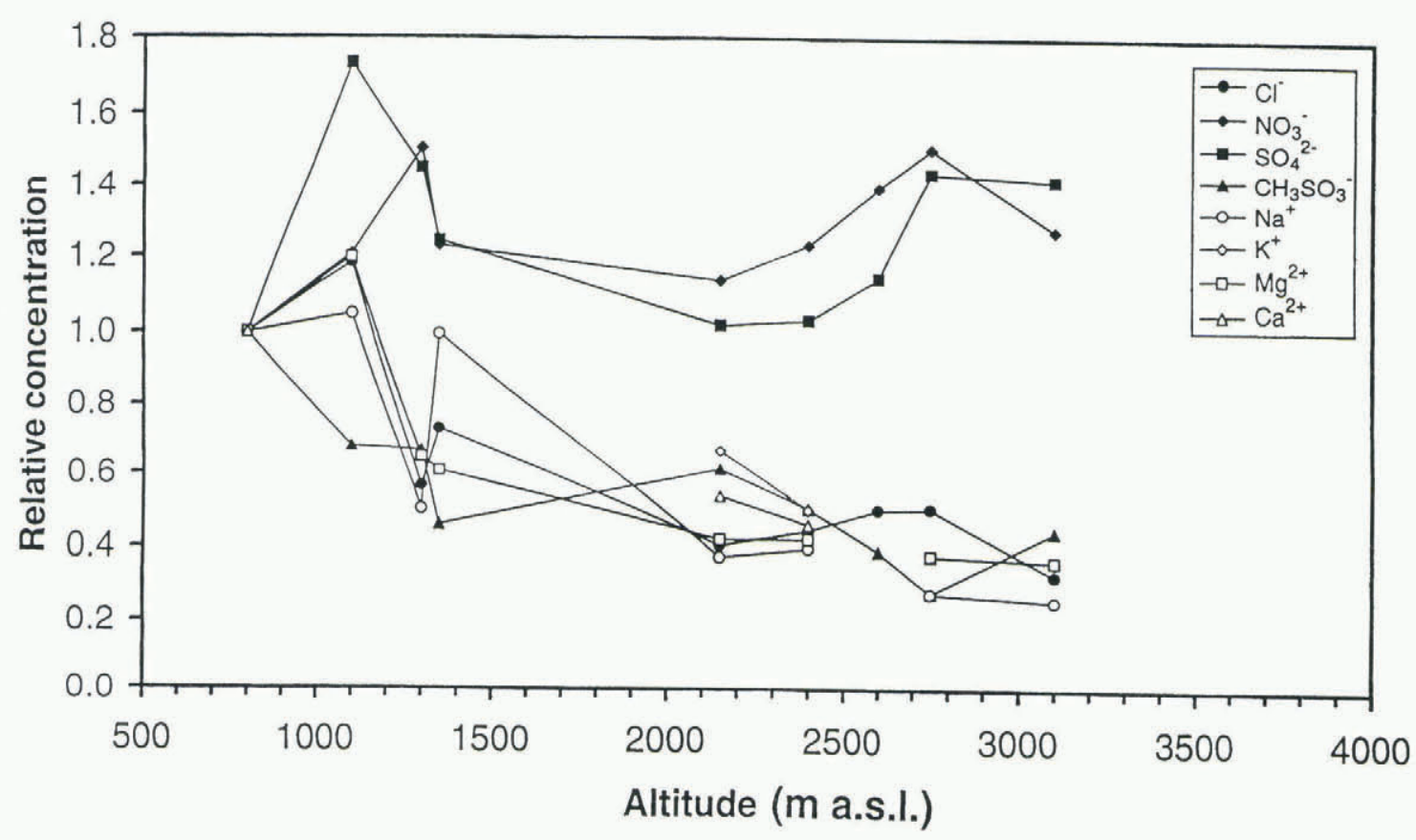

Fig. 5. Relative concentrations of ions at each site vs altitude.

\section{Spatial variability of ions}

Spatial variability of the ion concentrations in the snow are, except for post-depositional processes, determined by the relationship between different parameters such as altitude, distance from coast, temperature, accumulation rate and aerosol properties. In this area the distance from the coast and the altitude are positively correlated, as shown in Figure 2. The relationship between temperature (and $\delta^{18} \mathrm{O}$ ), accumulation rate and altitude is evident from Figure 4 . The higher the altitude, the lower the temperature and the lower the accumulation rate. Thus, the parameters are not independent of each other.

The different ions have very different absolute concentrations and they have therefore been plotted as relative concentrations and deposition fluxes in order to compare the spatial trends. The deposition fluxes were calculated based on the accumulation rate at each site. The concentrations have been normalized (conc. at site $\mathrm{X} /$ conc. at site l) to the most coastal site. Relative mean concentration against altitude for each snow pit and ion is shown in Figure 5. The ions can be divided into two different groups, the sea-salt elements $\left(\mathrm{Na}^{+}, \mathrm{K}^{+}, \mathrm{Mg}^{2+}, \mathrm{Ca}^{2+}, \mathrm{Cl}^{-}\right)$and $\mathrm{CH}_{3} \mathrm{SO}_{3}{ }^{-}$in one group, and $\mathrm{NO}_{3}{ }^{-}$and $\mathrm{SO}_{4}{ }^{2-}$ in the other group. The sea-salt elements and $\mathrm{CH}_{3} \mathrm{SO}_{3}{ }^{-}$show a decreasing trend in concentration towards the high-altitude plateau, with a more rapid decline at the mountain range Heimefrontfjella (Fig. 5), which most likely acts as an abrupt barrier for the maritime air masses. Nitrate and sulfate show a constant or slightly increasing trend with increasing altitude. The same division into two groups of ions is evident when looking at the relative deposition fluxes (Fig. 6). Because of the almost

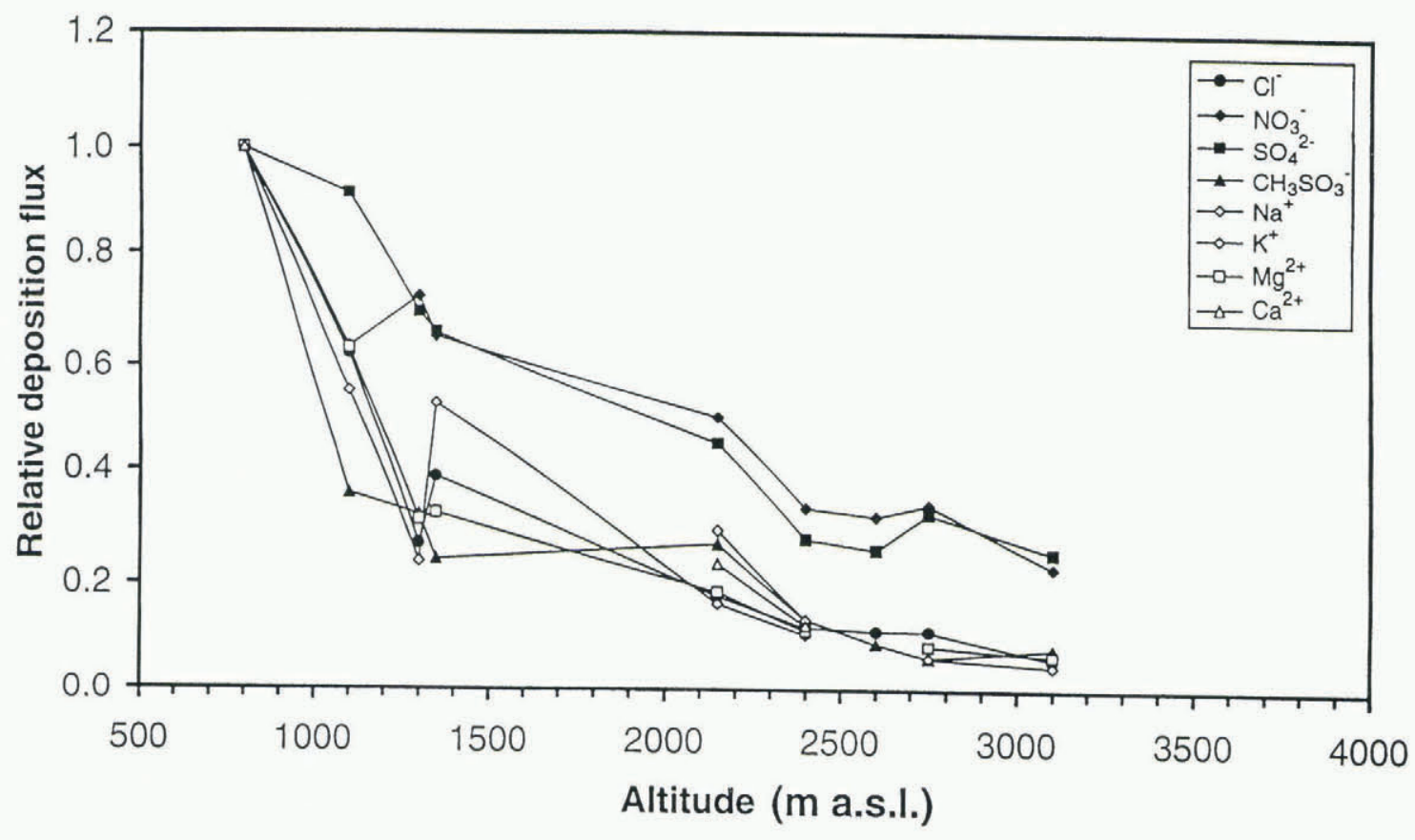

Fig. 6. Relative deposition fluxes of ions at each site vs altitude. 


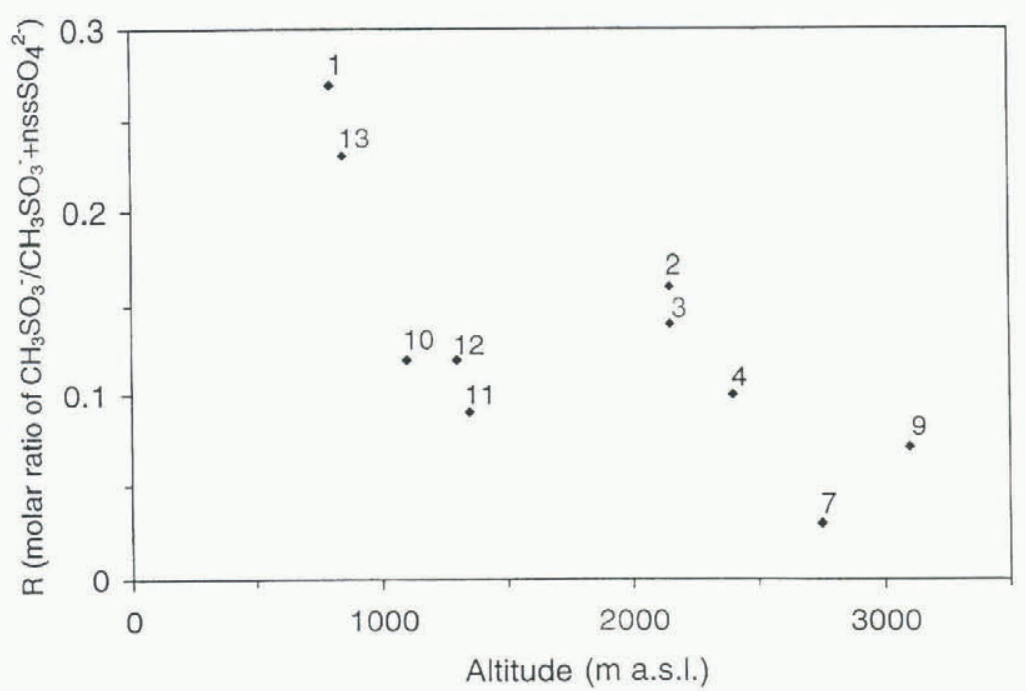

Fig. 7. Mean value of the molar ratio $\mathrm{R}\left(\mathrm{CH}_{3} \mathrm{SO}_{3}^{-} /\left(\mathrm{CH}_{3} \mathrm{SO}_{3}^{-}+n \mathrm{ssO}_{4}{ }^{2-}\right)\right)$ at each site vs altitude.

linear relationship in this area between the altitude and the distance from the sea (Fig. 2), the same pattern is obtained when plotting the concentrations against the distance from the sea. Mulvaney and Wolff (1994) found a more rapid decrease in concentrations with distance from the sea in an area with steep coastal topography compared to an area with open topography as on an open ice shelf. This indicates that the altitude has more influence on the concentrations of ions in the snow than the distance from the sea, which can be interpreted as meaning that different air masses are influencing different altitudes. The local marine air masses are only reaching a certain altitude, while long-range transported air masses are influencing the high-altitude plateau.

Both $\mathrm{SO}_{4}{ }^{2-}$ and $\mathrm{CH}_{3} \mathrm{SO}_{3}{ }^{-}$are products of marine biogenic production through the oxidation of dimethyl sulfide (DMS) released from phytoplankton. Sulfate may also originate from sea spray, volcanic emissions and stratospheric input, while $\mathrm{CH}_{3} \mathrm{SO}_{3}$ only originates from DMS oxidation. The $\mathrm{CH}_{3} \mathrm{SO}_{3}{ }^{-}$fraction of the sulfur species, commonly denoted $R$ (defined as $\mathrm{CH}_{3} \mathrm{SO}_{3}{ }^{-} /\left(\mathrm{CH}_{3} \mathrm{SO}_{3}{ }^{-}+\mathrm{nssSO}_{4}{ }^{2}\right.$ ) (Whung and others, 1994)) varies within a range of 0.04 0.9 on the coast, and of $0.01-0.5$ on the high-altitude plateau. The value of $R$ in Antarctic snow has been suggested (Saigne and Legrand, 1987; Legrand and others, 1992) to indicate the location for the influencing marine source area at each site. The partitioning between $\mathrm{CH}_{3} \mathrm{SO}_{3}{ }^{-}$and $\mathrm{SO}_{4}{ }^{2-}$ during DMS oxidation is inferred (Berresheim, 1987) to be temperature-dependent from laboratory oxidation studies (Hynes and others, 1986). This temperature dependency is thought to be responsible for the observed latitudinal gradient of $R$ (Bates and others, 1992), with higher $R$ values found at higher latitudes.

The highest mean values for $R$ are found at the most coastal sites, with a maximum during summer, and the lowest furthest inland (Fig. 7; Table 2). This is in accordance with a local source for coastal sites, a high-latitude source which gives rise to a high $R$ value and a maximum during summer. The intensity of the sunlight is probably more important than a complete disappearance of the sea ice, which explains why the peak season is earlier than for the sea-salt elements. The high-altitude plateau is influenced by long-range transport, and thus the lower $R$ value could be explained by a marine biogenic source at lower latitudes. However, a lower $R$ value could also be due to a larger influ- ence of other sources for sulfate, like volcanic and anthropogenic sources at lower latitudes. The effect on the $R$ value of the Mount Pinatubo eruption is clearly seen in the dataset. However, one should be aware of the total dominance of the 1991-93 El Niño event in the coastal records, which could bias our interpretation of spatial differences.

\section{CONCLUSIONS}

We have presented depth profiles of eight ions and $\delta^{18} \mathrm{O}$ from 11 snow pits (1-2 $\mathrm{m}$ deep) in western Dronning Maud Land to reveal spatial variations in snow chemistry for this part of Antarctica where data are sparse. The depth profiles span 2-14 years. The $\delta^{18} \mathrm{O}$ values from this area are found to be suitable as proxy-temperature indicators with a $\delta^{18} \mathrm{O} / T$ gradient of $0.91 \%{ }^{\circ} \mathrm{C}^{-1}\left(r^{2}=0.98\right)$.

The spatial variability of the ions can be divided into two groups: one with sea-salt elements $\left(\mathrm{Na}^{+}, \mathrm{K}^{+}, \mathrm{Mg}^{2+}\right.$, $\mathrm{Ca}^{2+}, \mathrm{Cl}^{-}$) and methane sulfonate, and the other with nitrate and sulfate. For the first group the concentrations decrease, and for the second group the concentrations are constant or increase with increasing altitude and increasing distance from the coast, as well as with decreasing temperature and decreasing accumulation rate.

This pattern suggests that the sources for sea-salt elements and methane sulfonate are more local, whereas the sources for nitrate and sulfate are a mixture of local and long range transport. Although methane sulfonate and sulfate have one source in common, DMS oxidation, they show different spatial variability. This means that the ratio between methane sulfonate and sulfate should be used with caution to describe the location of the DMS source.

\section{ACKNOWLEDGEMENTS}

This traverse in the field was supported by SWEDARP. E. Huss assisted with drilling and sampling activities. The project was financed by the Swedish Natural Science Research Council. Grants for analyzing snow samples were received from Carl Mannerfelts fond, Lillemor och Hans W:son Ahlmanns fond för geografisk forskning, Stiftelsen Ymer-80 and the Swedish Society for Anthropology and Geography (SSAG). Valuable comments on the manuscript were made by C. Richardson and J.-O. Näslund. 


\section{REFERENCES}

Bates, T. S., B. K. Lamb, A. Guenther, J. Dignon and R. E. Stoiber. 1992 Sulfur emissions to the atmosphere from natural sources. F. Atmos. Chem., 14(1-4), 315-337.

Berresheim, H. 1987. Biogenic sulfur emissions from the subantarctic and Antarctic oceans. F. Geophys. Res., 92(D11), 13,245-13,262.

Cacciani, M., P. di Girolamo, A. di Sarra, G. Fiocco and D. Fua. 1993 Volcanic aerosol layers observed by lidar at South Pole, September 1991-June 1992. Geophys. Res. Lett., 20 (9), 807-810.

Dansgaard, W. 1964, Stable isotopes in precipitation. Tellus, 16(4), 436-468.

Dansgaard, W., S. J. Johnsen, H. B. Clausen and N. Gundestrup. 1973. Stable isotope glaciology. Medd. Gronl., $197(2)$.

Dibb, J. E. and S. Whitlow. 1996. Recent climatic anomalies and their impact on snow chemistry at South Pole, 1987-1994. Geophys. Res. Lett., $23(10), 1115-1118$

Gjessing, Y. 1984. Marine and non-marine composition of the chemical composition of the snow at the Riiser-Larsen Ice Shelf in Antarctica. Atmos, Environ., 18 4), 825-830.

Hoffmann, S., S. J. Oltmans, J. A. Lathrop, J. M. Harris and H. Vömel. 1994. Record low ozone at the South Pole in the spring of 1993. Geophys. Res. Lett., 21 (6), 421-424.

Hynes, A. J., P. H. Wine and D. H. Semmes. 1986. Kinetics and mechanism of $\mathrm{OH}$ reactions with organic sulfides. 7. Phys. Chem., $90(17), 4148-4156$.

Isaksson, E. 1994. Changes in climate and atmospheric conditions between 1865-1991 inferred from a high altitude snow core, Dronning Maud Land, Antarctica. (Ph.D. thesis, Stockholm University. Department of Physical Geography.)

Isaksson, E. and W. Karlén. 1994a. High resolution climatic information from short firn cores, western Dronning Maud Land, Antarctica. Climatic Change, 26(4), 421-434

Isaksson, E. and W. Karlén. 1994b. Spatial and temporal patterns in snow accumulation, western Dronning Maud Land, Antarctica. 7. Glaciol., 40 (135), 399-409.

Isaksson, E., W. Karlén. N. Gundestrup, P. Mayewski, S. Whitlow and M Twickler. 1996. A century of accumulation and temperature changes in Dronning Maud Land, Antarctica. f. Geophys. Res., 101 (D3), 7085-7094.

Johnsen, S. J. 1977. Stable isotope homogenization of polar firn and ice. International Association of Hydrological Sciences Publication 118 (Symposium at Grenoble 1975 - Isotopes and Impurities in Snow and Ice ), 210-219.

Legrand, M. R. and R. J. Delmas. 1988. Formation of $\mathrm{HCl}$ in the Antarctic atmosphere. 7. Geophys. Res., 93(D6), 7153-7168.

Legrand, M. and C. Feniet-Saigne. 1991. Methanesulfonic acid in south polar snow layers: a record of strong EI Niño? Geophys. Res. Lett., 18(2), 187-190.

Legrand, M., C. Feniet-Saigne, E. S. Saltzman and C. Germain. 1992 Spatial and temporal variations of methanesulfonic acid and non sea salt sulfate in Antarctic ice. F. Atmos. Chem., 14(1-4), 245-260.

Lorius, C. and L. Merlivat. 1977. Distribution of mean surface stable isotope values in East Antarctica. International Association of Hydrological Sciences Publication 118 (Symposium at Grenoble 1975 - Isotopes and Impurities in Snow and Ice ), 127-137.

Mulvaney, R. and E.W. Wolff. 1994. Spatial variability of the major chemistry of the Antarctic ice sheet. Ann. Glaciol., 20,440-447.

Mulvaney, R., F. J. Coulson and F. J. Corr. 1993. The fractionation of sea salt and acids during transport across an Antarctic ice shelf. Tellus, 45B(2), $179-187$.

Näslund, J.-O., V. Pohjola and A. Stroeven. 1991. Glaciological surveys in Vestfjella and Heimafrontfjella, Dronning Maud Land, Antarctica, 1989/90. Stockholms Universitet. Naturgeografiska Institutionen. Forskningsrapport $83,1-71$.

Neubauer, J. and K. G. Heumann. 1988. Nitrate trace determinations in snow and firn core samples of ice shelves at the Weddell Sea, Antarctica. Atmos. Environ., 22 (3), 537-545.

Qin Dahe, J. R. Petit, J. Jouzel and M. Stievenard. 1994. Distribution of stable isotopes in surface snow along the route of the 1990 International Trans-Antarctica Expedition. J. Glaciol., 40(134), 107-118.

Richardson, C., E. Aarholt, S.-E. Hamran, P. Holmlund and E. Isaksson. 1997. Spatial distribution of snow in western Dronning Maud Land, East Antarctica, mapped by a ground-based snow radar. 7. Geophys. Res., 102(B9), 20,343-20,354.

Saigne, C. and M. Legrand. 1987. Measurements of methanesulphonic acid in Antarctic ice. Nature, $330(6145), 240-242$.

Saxena, V. K., J. Anderson and N. H. Lin. 1995. Changes in Antarctic stratospheric aerosol characteristics due to volcanic eruptions as monitored by the Stratospheric Aerosol and Gas Experiment II satellite. 7. Geophys. Res., $\mathbf{1 0 0}$ (D8), 16,735-16,751.

Wagenbach, D., U. Görlach, K. Moser and K.O. Münnich. 1988. Coasta Antarctic aerosol: the seasonal pattern of its chemical composition. Tellus, 40B (5), 426-436.

Whung, P.-Y., E. S. Saltzman, M. J. Spencer, P. A. Mayewski and N. Gundestrup. 1994. Two-hundred-year record of biogenic sulfur in a south Greenland ice core (20D). J. Geophys. Res., 99(DI), 1147-1156. 